\title{
SUPLEMENTASI KELAPA KOPYOR TERHADAP AKTIVITAS SUPEROKSIDA DISMUTASE DAN PATOLOGI ANATOMI HATI TIKUS AKIBAT PERLAKUAN PARASETAMOL
}

\author{
Akhmad Endang Zainal Hasan ${ }^{*}$, Hasim ${ }^{1}$, Agus Setiyono ${ }^{2}$, dan Sekar Winahyu Ariadini ${ }^{1}$ \\ ${ }^{1}$ Departemen Biokimia, FMIPA IPB. \\ ${ }^{2}$ Departemen Klinik, Reproduksi dan Patologi, FKH, IPB \\ *email:zainalhasan@ipb.ac.id; pakzainalhasan@gmail.com
}

\begin{abstract}
This research aimed at determining of the effects of the induction of paracetamol and kopyor coconut on the activity of superoxide dismutase (SOD) and pathologic anatomy of rat's liver. Previous research shows that paracetamol caused negative effect to the body while kopyor coconut has the ability to improve human health, related to its capacity to prevent oxidative damage of human body. In this research, the positive effect of kopyor is approached through measurement of body weight and the activity of the total SOD enzyme of animals tested, which are induced by paracetamol and fed with kopyor. Rat's administered with temulawak were positive control. The result showed that paracetamol treatment using toxic dose was found to reduce body weight of tested animals. Meanwhile, both kopyor and temulawak supplements were able to counter the negative effect of paracetamol, indicated by the increase in the body weight of tested animals. Other results showed that treatments with temulawak and 5 times-dose of kopyor supplement demonstrated a significantly high total SOD activity in the liver as compared to negative control. Furthermore, pathologic observation of the tested animals' liver showed that 5 time-dose of kopyor treatment was confirmed to improve the recovery of the liver caused by negative effect of paracetamol, better than the negative control.
\end{abstract}

Key words: kopyor coconut, superoxide dismutase, free radical, pathologic

\section{PENDAHULUAN}

Radikal bebas merupakan unsur atau senyawa sangat reaktif yang memiliki satu atau lebih elektron yang tidak berpasangan. Sifat reaktif radikal bebas dapat merusak jaringan tubuh sehingga dapat menimbulkan berbagai macam penyakit metabolis, seperti kanker, penyakit pembuluh darah, disfungsi otak dan sistem saraf.

Unsur atau senyawa radikal bebas secara alami sudah terbentuk di dalam tubuh melalui berbagai proses kimiawi yang kompleks. Radikal bebas ini merupakan hasil samping dari proses oksidasi dalam sel yang berlangsung pada waktu seseorang bernafas, melakukan kegiatan olah raga yang berlebihan, mengkonsumsi alkohol, mengalami peradangan atau ketika tubuh berhadapan dengan polusi lingkungan seperti asap kendaraan bermotor, asap rokok, radiasi matahari dan sebagainya. Jumlah radikal bebas yang dihasilkan tergantung pada jenis kegiatan yang dilakukan.

Antioksidan adalah zat yang mampu memperlambat atau mencegah proses oksidasi dan berfungsi untuk menghentikan kerusakan sel akibat radikal bebas. Salah satu mekanisme perlindungan tubuh mengatasi bahaya yang timbul akibat radikal bebas adalah peningkatan 
antioksidan endogen yang terdiri atas enzim-enzim dan berbagai senyawa yang disintesis tubuh (Asikin 2001). Enzimenzim seperti katalase, glutation peroksidase, dan superoksida dismutase (SOD) merupakan antioksidan endogen yang dapat ditemukan pada berbagai jaringan tubuh (Gitawati 1995).

Superoksida dismutase merupakan enzim yang mengakatalisis dismutasi ion superoksida radikal $\left(\mathrm{O}_{2}{ }^{-}\right)$menjadi hidrogen peroksida $\left(\mathrm{H}_{2} \mathrm{O}_{2}\right)$ dan molekul oksigen $\mathrm{O}_{2}$. Berdasarkan kofaktor logam dan distribusinya di dalam tubuh, SOD terbagi atas 3 tiga macam, yaitu copper, zinc superoxide dismutase $(\mathrm{Cu}, \mathrm{Zn}-\mathrm{SOD})$ yang umumnya terdapat dalam sitoplasma eukariot, manganase superoxide dismutase (Mn-SOD) yang biasanya terdapat pada mitokondria organisme aerobik, iron superoxide dismutase (Fe-SOD) yang biasanya terdapat pada prokariot (Mates et al. 1999; Nurwati 2002), dan extracellular superoxide dismutase (ec-SOD) yang banyak ditemukan pada cairan ekstraselular pada mamalia (West dan Prohaska 2004).

SOD tergolong enzim yang sangat stabil karena tiap subunit tergabung oleh ikatan non-kovalen dan terangkai oleh rantai disulfida (Fridovich 1986). Enzim ini memainkan $\mathrm{p}$;htgeranan yang sangat penting pada garis depan sistem pertahanan antioksi dan (Mates et al. 1999). Aktivitas SOD bervariasi pada beberapa organ tikus, terdapat dalam jumlah tertinggi di dalam hati, kemudian berturut-turut dalam kelenjar adrenal, ginjal, limpa, pankreas, otak, paru-paru, lambung, usus, ovarium, timus, dan lemak (Nurwati 2002)

\begin{tabular}{cccc}
\multicolumn{2}{c}{ Antioksidan } & dalam & tubuh \\
mempunyai & batas & tertentu & untuk \\
menangkal & radikal & bebas. & Untuk
\end{tabular} meningkatkan efektivitas antioksidan, beberapa nutrien penting sangat diperlukan oleh tubuh. Efektivitas enzim SOD dapat ditingkatkan dengan adanya nutrien mineral seperti tembaga $(\mathrm{Cu})$ dan Seng (Zn) dan mangan (Mn) (Kartikawati 1999;
Tuminah 2000; West dan Prohaska 2004). Kandungan nutrisi yang tinggi pada kelapa kopyor dapat dimanfaatkan sebagai salah satu sumber dan mineral yang penting untuk tubuh, salah satunya adalah sebagai kofaktor antioksidan alami SOD yang terdapat dalam tubuh. Air kelapa kopyor mengandung mineral $\mathrm{Mn}, \mathrm{K}, \mathrm{P}, \mathrm{S}$, dan $\mathrm{Mg}$ dalam jumlah yang cukup tinggi, sedangkan pada daging buah kelapa kopyor, kandungan mineral terbanyak adalah $\mathrm{Fe}, \mathrm{Zn}$, dan $\mathrm{Al}$ (Santoso et al. 1996).

Berdasarkan pernyataan di atas, dilakukan penelitian untuk membuktikan bahwa suplemen gizi buah kelapa kopyor dapat meningkatkan kerja antioksidan SOD pada tubuh tikus yang diinduksi parasetamol. Hasil penelitian yang diperoleh diharapkan dapat memberikan informasi ilmiah mengenai potensi kelapa kopyor sebagai sumber mineral kofaktor antioksidan, yang dapat mencegah kerusakan oksidatif akibat induksi parasetamol, dan meningkatkan nilai tambah kelapa kopyor.

\section{BAHAN DAN METODE Bahan}

Hewan uji yang digunakan adalah tikus putih jantan galur Sprague-Dawley yang diperoleh dari Fakultas Kedokteran Hewan, Institut Pertanian Bogor (IPB), berumur 2 bulan, dan berbobot badan 150200 g. Kelapa kopyor yang digunakan diperoleh dari Balai Penelitian Bioteknologi Perkebunan Indonesia (BPBPI). Bahan-bahan yang digunakan adalah kelapa kopyor, temulawak, akuades, homogenat hati 10\%, kloroform, alkohol $70 \%$, riboflavin $0.12 \mathrm{mM}$, nitroblue tetrazolium (NBT), bovine serum albumine (BSA), $\mathrm{NaCl}$ 0.9\% (b/v), EDTA $0.1 \mathrm{M}, \mathrm{KCN} 0.3 \mathrm{mM}$, dan bufer fosfat $0.0067 \mathrm{M} \mathrm{pH} 7.8$.

\section{Metode}

Hewan Coba dan Rancangan Percobaan

Hewan percobaan yang digunakan adalah tikus putih galur Sprague-Dawley 
sebanyak 18 ekor dengan jenis kelamin jantan, sehat, dan mempunyai aktivitas normal. Tikus dipelihara dalam kandang individual berukuran $30 \times 50 \times 50 \mathrm{~cm}$ dan diadaptasikan selama 2 minggu kemudian diberi perlakuan. Sebelum dan selama perlakuan, tikus diberi pakan standar dan minum secara ad libitum. Bobot badan tikus dan jumlah pakan yang digunakan diamati setiap hari.

Induksi parasetamol dilakukan menurut metode Gupta et al. (2006) yang dimodifikasi. Induksi kerusakan hati dilakukan dengan memberikan parasetamol secara oral dengan dosis 500 $\mathrm{mg} / \mathrm{kg}$ BB/hari selama 7 hari yang dilanjutkan dengan penambahan dosis menjadi $600 \mathrm{mg} / \mathrm{kg}$ BB selama 7 hari berikutnya sebagai modifikasi metode.

Tikus dibagi menjadi 6 kelompok dengan 3 ekor tikus dalam setiap kelompok. Kelompok I hanya diberikan pakan standar $(\mathrm{N})$. Kelompok II (kontrol positif $=\mathrm{K}+$ ) diberikan pakan standar, diinduksi dengan parasetamol selama 14 hari, dan diberi suplemen temulawak dengan dosis $3 \mathrm{~g} / \mathrm{kg}$ BB selama 21 hari. Kelompok III (kontrol negatif=K-) diberikan pakan standar dan parasetamol selama 14 hari. Kelompok IV, V, dan VI merupakan kelompok perlakuan (P) dan masing-masing diberi pakan standar, diinduksi dengan parasetamol selama 14 hari, dan diberi suplemen daging kelapa kopyor yang dihaluskan. Setelah induksi parasetamol, kelompok perlakuan diberi suplemen kelapa kopyor selama 21 hari masing-masing dengan dosis 4, 12, dan 20 g/kg BB (P1, P2 dan P3) melalui sonde sedangkan untuk kontrol positif diberi temulawak. Setelah perlakuan selesai, dilakukan nekropsi, pengambilan organ hati, dan pengamatan gambaran patologi anatomi hati.

\section{Pengamatan Fisik.}

Pengamatan fisik hewan coba yang diamati meliputi bobot badan, konsumsi pakan, keadaan fisik, dan tingkah laku. Bobot badan dan konsumsi pakan diamati dengan menimbang tikus serta bobot pakan sebelum dan sesudah pemberian pakan. Keadaan fisik pada tikus yang diamati adalah warna mata dan kerontokan bulu. Tingkah laku yang diamati meliputi mobilitas dan agresivitas.

\section{Fraksinasi Hati untuk Analisis Enzim SOD}

Setelah perlakuan selesai, tikus dinekropsi dengan dekapitasi setelah dibius dengan kloroform. Tikus dibedah dan diambil hatinya. Hati dibilas dengan larutan $\mathrm{NaCl}$ 0,9\% (cairan fisiologis) untuk membersihkan dari kotoran dan darah. Sebanyak $1 \mathrm{~g}$ hati ditimbang dan ditambahkan larutan $\mathrm{NaCl} 0,9 \%$ kemudian dihaluskan dengan homogenizer PotterElvehjem. Homogenat $10 \%$ ini kemudian disentrifus pada $700 \mathrm{x}$ g suhu $4{ }^{\circ} \mathrm{C}$ selama 10 menit. Supernatan yang diperoleh dipisahkan, kemudian diambil sebanyak $1 \mathrm{ml}$ untuk dihancurkan dengan ultrasonikator selama 5 menit.

\section{Analisis Protein Total (Bradford 1976) Pembuatan Kurva Standar.}

Pembuatan kurva standar digunakan larutan BSA $1.56 \mathrm{mg} / \mathrm{mL}$ dan $1.5 \mathrm{mg} / \mathrm{mL}$ sebagai larutan standar. Larutan BSA dimasukkan ke dalam tabung reaksi sebanyak 10, 30, 50, 70 dan $90 \mu \mathrm{L}$ lalu ditambahkan larutan $\mathrm{NaCl} \quad 0.9 \%$ sehingga volume total setiap tabung 100 $\mu \mathrm{L}$. Blanko digunakan larutan $\mathrm{NaCl} 0.9 \%$ $100 \mu \mathrm{L}$, tanpa penambahan larutan BSA. Masing-masing tabung ditambahkan pereaksi Bradford sebanyak $2.9 \mathrm{~mL}$ kemudian dikocok dengan vortex. Sebelum diukur, larutan didiamkan selama 5 menit. Serapan larutan standar diukur pada panjang gelombang $(\lambda) 595 \mathrm{~nm}$.

\section{Analisis Protein Total Sampel.}

Sebanyak $10 \mu \mathrm{L}$ sampel dan $90 \mu \mathrm{L}$ $\mathrm{NaCl} 0.9 \%$ dimasukkan ke dalam tabung reaksi kemudian ditambahkan $2.9 \mathrm{ml}$ pereaksi Bradford kemudian dikocok hingga merata dengan vortex. Sebelum diukur, larutan didiamkan selama 5 menit. 
Serapan sampel juga diukur pada panjang gelombang $(\lambda) 595 \mathrm{~nm}$.

\section{Analisis Enzim SOD (Winterbourn et al. 1975)}

Prinsip pengukuran aktivitas SOD
dengan metode ini berdasarkan kemampuan enzim SOD dalam menghambat reduksi NBT oleh radikal anion superoksida. NBT yang tereduksi akan membentuk kompleks formazan yang berwarna biru ungu. Adanya enzim SOD dalam sampel akan menghambat pembentukkan kompleks warna tersebut. Kepekatan warna sampel menunjukan jumlah enzim SOD dalam sampel tersebut.

Analisis enzim dilakukan dengan memasukkan sampel yang mengandung 10 $\mu \mathrm{g}$ protein ke dalam kuvet yang mengandung $67 \mu \mathrm{L}$ EDTA $0.1 \mathrm{M}$ untuk mengukur SOD total. Kemudian ditambahkan $33 \mu \mathrm{L}$ NBT $1.5 \mathrm{mM}$ serta

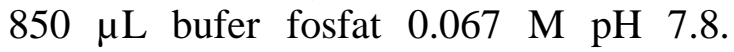
Selanjutnya kuvet diinkubasi dalam kotak cahaya yang menggunakan lampu fluoresent 40 watt selama 5 menit kemudian ditambahkan $25 \mu \mathrm{L}$ riboflavin $0.12 \mathrm{mM}$ dan diinkubasi kembali dalam kotak. Setiap 1 menit diukur serapannya pada $\lambda 560 \mathrm{~nm}$. Aktivitas enzim yang terukur merupakan aktivitas spesifik.

\section{Analisis Statistik}

Data yang diperoleh diuji dengan menggunakan analisis statistik ANOVA untuk mengetahui pengaruh perlakuan pada selang kepercayaan 90\% (Matjik dan Sumertajaya 2002).

\section{HASIL DAN PEMBAHASAN Bobot Badan \\ Hasil pengaruh induksi parasetamol dan penambahan suplemen kelapa kopyor dan temulawak terhadap bobot badan (BB) hewan coba dapat}

terlihat pada Gambar 1. Pengamatan pada hari ke-14 menunjukkan secara umum seluruh kelompok mengalami penurunan BB. Penurunan BB yang paling kecil ditunjukkan oleh kelompok normal $(\mathrm{N}$, akuades 35 hari), yaitu sebesar $0.5 \%$, sedangkan penurunan $\mathrm{BB}$ hewan coba yang paling tajam terjadi pada kelompok K- (induksi parasetamol 14 hari + akuades 21 hari), yaitu sebanyak $11.4 \%$. Kelompok $\mathrm{K}+$ (induksi parasetamol 14 hari + suplemen temulawak 21 hari), P1 (induksi parasetamol 14 hari + suplemen kelapa kopyor 1x dosis 21 hari), P2 (induksi parasetamol $3 \mathrm{x}$ dosis 21 hari), dan $\mathrm{P} 3$ (induksi parasetamol 14 hari + suplemen kelapa kopyor $5 \mathrm{x}$ dosis 21 hari) juga mengalami penurunan, berkisar antara 2 hingga $8 \%$ Berdasarkan hasil tersebut diduga bahwa pemberian parasetamol dalam dosis toksik mempengaruhi nafsu makan yang berakibat pada menurunnya BB. Menurut Gan (1980), toksisitas parasetamol akan menimbulkan gejalagejala anoreksia, mual, muntah, serta sakit perut yang terjadi dalam 24 jam pertama, dan dapat berlangsung terus menerus selama seminggu atau lebih. Gejala-gejala inilah yang menyebabkan nafsu makan menurun sehingga berpengaruh terhadap BB hewan coba tersebut. Uji statistik BB pada hari ke-14 menunjukkan adanya beda nyata $(\mathrm{P} \leq 0.1)$ antara kelompok normal dengan perlakuan $(\mathrm{K}+, \mathrm{K}-, \mathrm{P} 1, \mathrm{P} 2$, dan P3). Pengamatan pada hari ke-35 menunjukkan adanya kenaikan BB secara umum pada seluruh kelompok dengan instensitas yang berbeda. Kelompok $\mathrm{N}$ dan $\mathrm{K}+$ merupakan kelompok yang paling banyak mengalami kenaikan $\mathrm{BB}$, yaitu masing-masing $20 \%$ dan $13 \%$. Kelompok $\mathrm{K}, \mathrm{P} 1, \mathrm{P} 2$, dan P3 mengalami kenaikan BB namun tidak begitu tinggi, berkisar antara 6 hingga $11 \%$. 


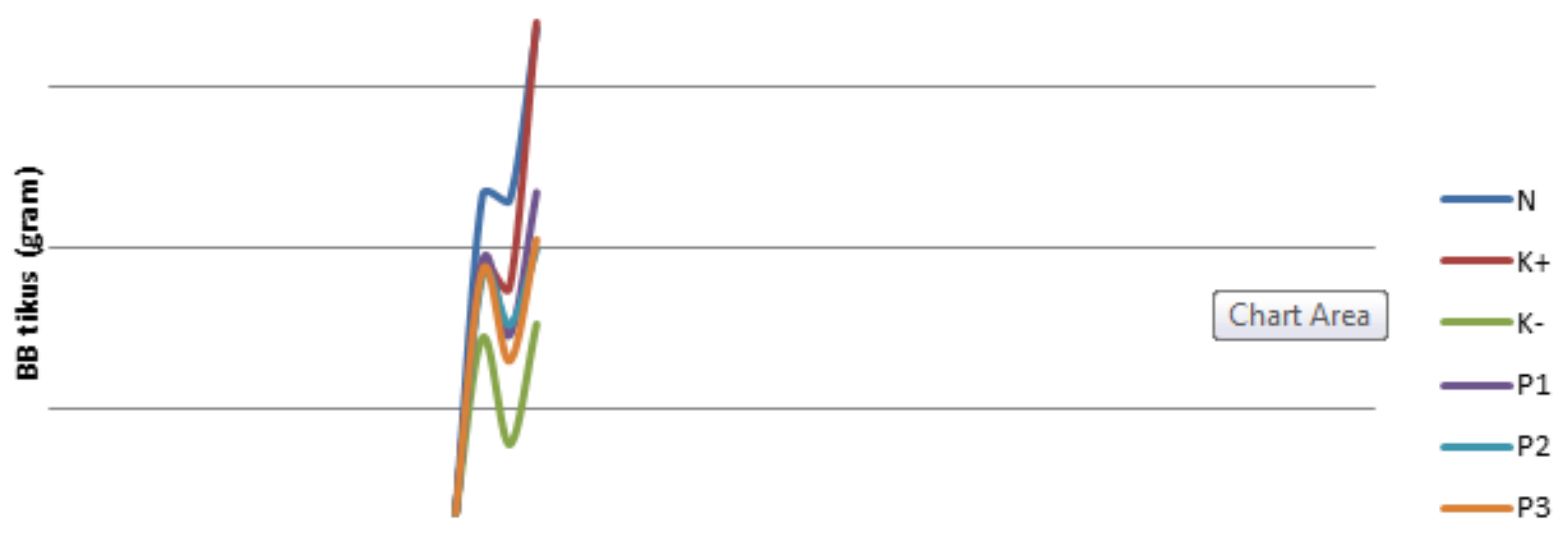

$\begin{array}{ll}-14 & -7\end{array}$

Hari ke-

Gambar 1 Bobot badan tikus saat pemberian parasetamol (hari ke-0 hingga hari ke-14) dan pemberian suplemen kelapa kopyor (hari ke-15 hingga hari ke-35)

Berdasarkan hasil tersebut, diduga bahwa pemberian suplemen temulawak mempengaruhi nafsu makan yang akan menaikkan BB. Hal ini sesuai dengan penelitian Liang et al. (1985) yang menyatakan bahwa temulawak dapat digunakan sebagai obat untuk mengatasi gangguan saluran pencernaan, gangguan aliran getah empedu, diare, kurang nafsu makan, radang lambung dan dapat mencegah terjadinya pelemakan dalam selsel hati. Selain itu kandungan kurkuminoid pada temulawak dapat berfungsi untuk meningkatkan produksi dan sekresi empedu. Kemampuan temulawak menghasilkan senyawa antibakteri mempengaruhi kerja mikroflora usus sehingga proses pencernaan menjadi lebih optimal. Berbagai penelitian terhadap hewan percobaan telah membuktikan bahwa temulawak memberikan dampak positif terhadap kandungan empedu, hati dan pankreas.

Pertambahan BB juga terjadi pada kelompok P1, P2, dan P3. Berdasarkan hasil tersebut, diduga bahwa pemberian suplemen kelapa kopyor juga mempengaruhi nafsu makan. Kandungan nutrisi pada kelapa kopyor, seperti vitamin, mineral, dan asam lemak diduga dapat membantu meningkatkan nafsu makan. Berdasarkan hasil penelitian menggunakan babi yang diberi pakan yang kaya akan kandungan asam lemak jenuh, babi tersebut mengalami obesitas, peningkatan kadar kolesterol dan LDL di dalam darah sedangkan kadar lipoprotein densitas tinggi (HDL) menurun. Selain itu, babi juga mengalami penyempitan pembuluh darah atau aterosklerosis (Bruce Fife 2001 diacu dalam Sulistyo 2004). Uji statistik BB pada hari ke-35 menunjukkan adanya beda nyata $(\mathrm{P} \leq 0.1)$ antara kelompok $\mathrm{N}$ dengan perlakuan (K-, P1, P2, dan P3).

\section{Enzim Superoksida Dismutase (SOD)}

Pengaruh penambahan suplemen kelapa kopyor terhadap aktivitas enzim SOD total terlihat pada Gambar 2. Dibandingkan kelompok normal (N), aktivitas SOD total pada kelompok yang mula-mula diinduksi parasetamol $(\mathrm{K}+, \mathrm{K}-$, P1, P2, dan P3) memiliki nilai aktivitas enzim SOD total yang lebih rendah. Persentase penurunan aktivitas SOD paling tinggi terjadi pada kelompok K-, yaitu $25 \%$, dan penurunan paling rendah 
terjadi pada kelompok $\mathrm{K}+$ dan $\mathrm{P} 3$, yaitu sebesar $12 \%$.

Pada kelompok N, aktivitas enzim SOD total adalah $184,03 \mathrm{U} / \mathrm{mg}$ protein. Halliwell dan Gutteridge (1989) melaporkan bahwa aktivitas enzim SOD total pada hati mencit normal adalah 660 $\mathrm{U} / \mathrm{mg}$ protein. Aktivitas enzim ini diukur dengan perbandingan $\mathrm{KO}_{2}$ dalam larutan alkalin. Aktivitas enzim SOD total pada hati tikus normal yang diukur dengan menggunakan prinsip yang sama dengan metode Winterbourn dilaporkan oleh Peeters-Joris et al. (1975) sebesar 22 U/mg protein. Perbedaan hasil yang ditunjukkan antara literatur dan hasil penelitian kemungkinan disebabkan oleh perbedaan metode yang digunakan, cara pemecahan sel yang berbeda, jarak pencahayaan saat inkubasi, dan perlakuan yang diberikan, dan jenis hewan coba yang digunakan.
Kelompok $\mathrm{K}+\quad$ (diinduksi parasetamol 14 hari + suplemen temulawak 21 hari) memiliki aktivitas enzim SOD total sebanyak 158,37 U/mg protein. Nilai kelompok kontrol positif ini sedikit lebih rendah dibandingkan kelompok P3 (diinduksi parasetamol 14 hari + suplemen kelapa kopyor 5x dosis), yaitu $160,23 \mathrm{U} / \mathrm{mg}$ protein. Hal ini diduga terjadi karena kandungan mineral pada temulawak tidak sebanyak kandungan mineral yang terdapat pada kelapa kopyor.

Kelompok K- (diinduksi parasetamol 14 hari + akuades 21 hari ) mempunyai aktivitas enzim SOD total yang paling rendah dibandingan kelompok perlakuan yang lain. Hal ini diduga karena pada kelompok ini tidak didapat cukup asupan gizi yang dapat menunjang pembentukan enzim SOD, khususnya mineral.

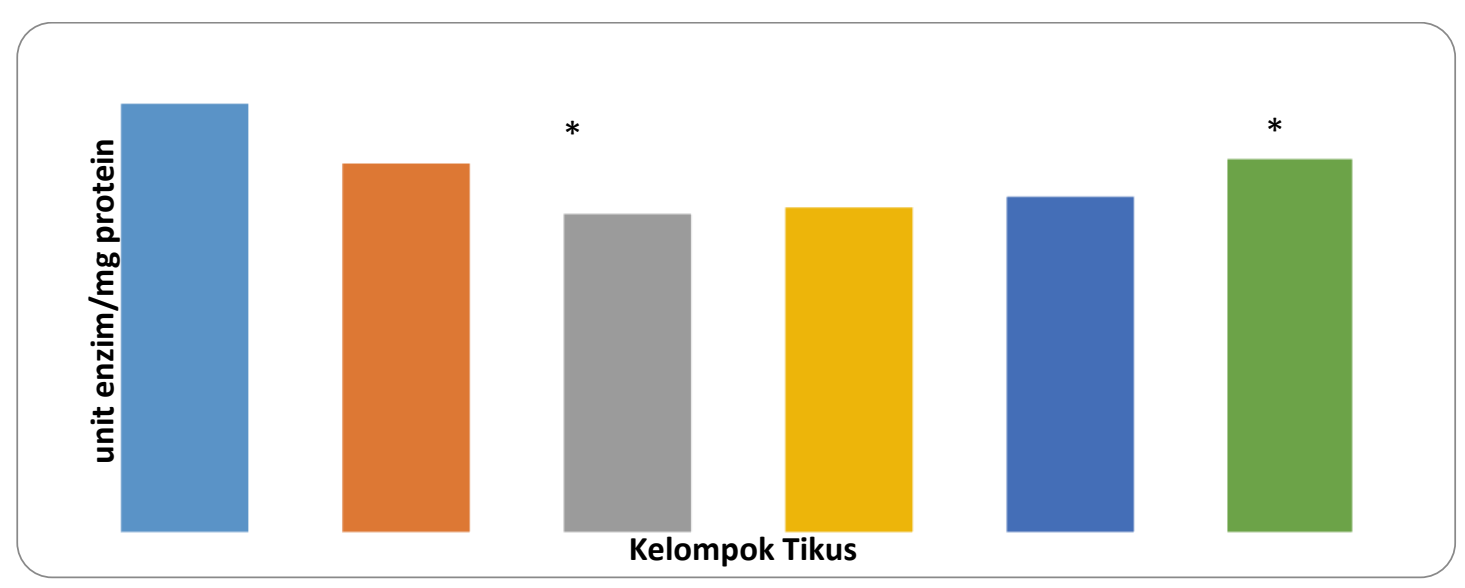

Gambar 2 Aktivitas enzim SOD total pada hari ke-35; *: berbeda nyata dengan K- pada taraf uji $10 \%$.

SOD merupakan metaloenzim yang sangat membutuhkan logam (mineral) pada sisi katalitiknya. Penelitian West dan Prohaska (2004) menunjukkan bahwa tikus yang dikondisikan kekurangan mineral, khususnya $\mathrm{Cu}$, mengalami penurunan aktivitas enzim SOD pada sel darah merahnya.
Pada kelompok perlakuan yang diinduksi parasetamol kemudian diberi suplemen kelapa kopyor 1x dosis (P1) dan $3 \mathrm{x}$ dosis (P2) terjadi kenaikan aktivitas enzim SOD total, namun dalam jumlah relatif sedikit. Hal ini diduga karena jumlah mineral yang dikonsumsi oleh kelompok ini lebih sedikit, sehingga mempengaruhi aktivitas enzim SOD. 
Hasil uji statistik aktivitas SOD total menunjukkan bahwa semua kelompok perlakuan $(\mathrm{K}+, \mathrm{K}-, \mathrm{P} 1, \mathrm{P} 2$, dan P3) berbeda nyata $(\mathrm{P} \leq 0,1)$ dengan kelompok normal $(\mathrm{N})$. Selain itu, dapat terlihat bahwa pada kelompok $\mathrm{K}+$ (diinduksi parasetamol 14 hari + suplemen temulawak 21 hari) dan P3 (diinduksi parasetamol 14 hari + suplemen kelapa kopyor 5x dosis) memberikan hasil statistik yang berbeda nyata $(\mathrm{P} \leq 0.1)$ dengan K- (diinduksi parasetamol 14 hari + akuades 21 hari). Pemberian suplemen kelapa kopyor $1 \mathrm{x}$ dosis (P1) dan 3x dosis (P2) mengalami peningkatan aktivitas SOD total, namun relatif lebih kecil, sehingga menurut perhitungan statistik tidak teramati perbedaannya secara nyata.

Pemberian parasetamol ditujukan untuk menghasilkan radikal bebas yang dapat menginduksi enzim SOD.

Hal ini sesuai dengan penelitian Dinu et al. (2005) yang menyatakan bahwa radikal bebas yang dihasilkan etanol dapat menginduksi produksi enzim antoksidan seperti SOD. Produksi dan aktivitas enzim SOD selanjutnya sangat dipengaruhi oleh beberapa faktor, antara lain tersedianya kofaktor yang diperlukan oleh enzim tersebut, lingkungan yang sesuai sehingga enzim tersebut dapat bekerja secara optimal, dan keberadaan inhibitor dan akselerator (Voet dan Voet 2002).

\section{Patologi Anatomi Hati}

Hasil pengamatan patologi anatomi hati tikus dapat terlihat pada Tabel 1 dan Gambar 3. Pada Tabel 1 menunjukkan bahwa pada kelompok normal tidak terdapat kelainan, warna yang ditunjukkan adalah coklat kemerahan dengan permukaan hati yang rata. Pada kelompok $\mathrm{K}+$ (diinduksi parasetamol 14 hari + suplemen kelapa kopyor) menunjukkan hati yang berwarna merah kecoklatan dan permukaan hati yang cenderung mulus. Hal ini didukung oleh penelitian yang dilakukan oleh Hadi (1985), yang menyatakan bahwa temulawak dapat mengobati gangguan hati dan kantung empedu, melancarkan sekresi empedu dan menurunkan kadar lemak serta anti peradangan (antiinflamasi). Penambahan ekstrak temulawak dalam etanol $50 \%$ nyata dapat memperbaiki sel-sel parenkim hati yang mengalami kerusakan akibat pemberian karbontertraklorida $\left(\mathrm{CCl}_{4}\right)$, hal ini menandakan bahwa rimpang temulawak mempunyai khasiat antihepatotoksik. Penelitian Hidayatullah (2006) tentang hepatotoksitas temulawak pada ayam diperoleh hasil bahwa pemberian sari kering temulawak sampai $400 \mathrm{mg} / \mathrm{kg}$ bobot badan ternyata tidak menampakkan fungsi hati yang menurun.

$$
\text { Kelompok K- (diinduksi }
$$

parasetamol 14 hari + akuades 21 hari) memperlihatkan hati dengan warna coklat kemerahan yang lebih tua dibandingkan normal. Permukaan yang ditunjukkan adalah belang, dan mengalami degenerasi. Belang yang terjadi pada permukaan hati merupakan salah satu indikasi bahwa hati mengalami degenerasi, sehingga dapat menurunkan kemampuan hati dalam memperbaiki sel yang rusak (Ressang 1984). Hal ini diduga karena pada kelompok ini hanya diberi pakan standar, sehingga kurang cukup mendapat asupan nutrisi yang dapat membantu regenerasi.

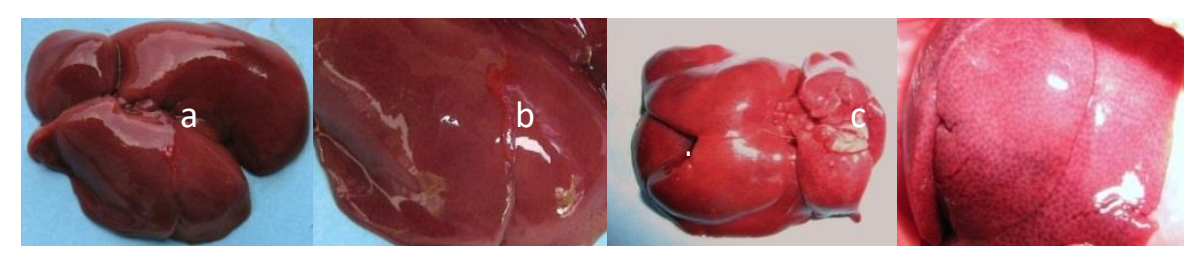


Gambar 3 (a) dan (b) Hati normal, (c) Hati rusak, (d) Hati rusak mengalami degenerasi dan lobulasi

Tabel 1 Hasil pengamatan patologi anatomi

\begin{tabular}{cccc}
\hline \multirow{2}{*}{$\begin{array}{c}\text { No Perla- } \\
\text { kuan }\end{array}$} & \multicolumn{2}{c}{ Hasil Pengamatan Patologi Anatomi } & $\begin{array}{c}\text { Skor } \\
\text { Degenerasi }\end{array}$ \\
\cline { 2 - 3 } N1 & Warna & Permukaan & - \\
N2 & Coklat & Mulus & - \\
N3 & kemerahan & & - \\
K+1 & Coklat & Cenderung rata & - \\
K+2 & kemerahan & & - \\
K+3 & Coklat & Belang, degenerasi & + \\
K-1 & kemerahan & Belang, degenerasi, & ++ \\
K-2 & lobulasi & ++ \\
K-3 & Coklat & & +++ \\
P1.2 & kemerahan & ++ \\
P1.3 & Coklat & Belang, degenerasi & ++ \\
P1.4 & & ++ \\
P2.1 & kemerahan & ++ \\
P2.2 & Belang degenerasi & ++ \\
P2.3 & Coklat & & + \\
P3.1 & kemerahan & & ++ \\
P3.2 & & + \\
P3.3 & & \\
\hline
\end{tabular}

Pengamatan patologi anatomi pada tikus yang diberi suplemen kopyor dengan dosis bertingkat (P1, P2, dan P3) menunjukkan adanya perbaikan kerusakan hati yang bervariasi, warna yang ditunjukkan adalah coklat kemerahan yang belang bervariasi pada setiap dosis perlakuan. Hal ini menunjukkan bahwa kelapa kopyor sebagai suplemen pada kelompok ini dapat memberikan efek perbaikan pada hati yang telah dirusak parasetamol. Pada kelompok 1x dosis (P1) dan 3x dosis (P2), belum terjadi perbaikan yang cukup baik. Hal ini ditunjukkan dengan terjadinya degenerasi dan permukaan hati yang cenderung tidak rata, namun pada kelompok $5 \mathrm{x}$ dosis (P3) terjadi perbaikan hati yang cukup baik. Hal ini ditunjukkan dengan tingkat degenerasi yang ringan dan permukaan hati yang cenderung rata dibandingkan kelompok perlakuan lain. Berdasarkan hasil tersebut, diduga penambahan suplemen kelapa kopyor dapat membantu perbaikan hati yang rusak. Hal ini disebabkan kandungan nutrisi pada kopyor, yaitu vitamin, mineral, dan asam lemak dapat membantu proses regenerasi sel hati. Kamath (1996) menyatakan bahwa nutrisi yang baik, konsumsi yang seimbang antara kalori, protein, lemak, karbohidrat, vitamin, serta mineral dapat membantu hati yang rusak untuk meregenerasi sel baru.

Nekropsi hewan percobaan pada hari terakhir pemberian parasetamol (hari ke-14) dilakukan untuk menunjukkan seberapa parah kerusakan yang ditimbulkan parasetamol setelah pemberian 2 minggu. Hasil nekropsi menunjukkan adanya kerusakan pada hati, antara lain terdapat bercak-bercak pada hati dan terdapat bilur steatosis yang tipis. Hal ini menunjukkan bahwa parasetamol dosis tinggi menimbulkan kerusakan organ, terutama pada hati. Peran daging kelapa kopyor dalam meningkatkan kadar enzim SOD ini terbukti dalam penelitian yang dilakukan oleh Hasan et al. (2013).

Menurut Gan (1980), akibat paling serius konsumsi parasetamol dosis toksik adalah nekrosis hati. Selain itu, nekrosis tubuli renalis dan koma hipoglikemik juga 
dapat terjadi. Gangguan hati mulai terjadi pada hari kedua keracunan parasetamol, gejala yang ditimbulkan adalah peningkatan aktivitas transaminase serum, dehidrogease laktat, konsentrasi bilirubin serum, serta pemanjangan masa protombin. Aktivitas fosfatase alkali dan konsentrasi albumin serum dapat tetap normal. Kerusakan hati dapat berakibat ensefalopati, koma, hingga kematian.

\section{KESIMPULAN}

Pemberian parasetamol dalam dosis toksik secara umum menurunkan bobot badan hewan coba. Pemberian suplemen temulawak dan suplemen kelapa kopyor dapat meningkatkan bobot badan hewan coba dengan intensitas yang berbeda. Uji aktivitas enzim superoxide dismutase total pada hati tikus menunjukkan bahwa kelompok yang diberi suplemen temulawak dan kelompok yang diberi suplemen kelapa kopyor dosis $20 \mathrm{~g} / \mathrm{kg}$ bobot badan berbeda nyata dengan kelompok yang hanya diberi akuades Pengamatan patologi anatomi pada hati tikus pada kelompok suplemen kelapa kopyor dosis $20 \mathrm{~g} / \mathrm{kg}$ bobot badan ternyata memberikan hasil perbaikan hati yang lebih baik dibandingkan kelompok yang hanya diberi akuades.

\section{UCAPAN TERIMA KASIH}

Diucapkan terima kasih kepada Direktur PT. Bintang Kelapa, Jakarta Indonesia atas dana penelitian yang diberikan. Terima kasih diucapkan pula kepada Ketua Departemen Biokimia, FMIPA IPB dan Ketua Departemen Klinik, Reproduksi dan Patologi, FKH, IPB yang telah memberikan fasilitas untuk penelitian ini.

\section{DAFTAR PUSTAKA}

Asikin, N. 2001. Antioksidan endogen dan penilaian status antioksidan. Makalah dalam kursus penyegaran dan pelatihan 2001. Radikal Bebas dan Antioksidan: Dasar, Aplikasi, dan Pemanfaatan Bahan Alam. Bagian Biokimia, Fakultas Kedokteran Universitas Indonesia. Jakarta. Hlm 1-6.

Bradford, M. 1976. A rapid and sensitive method for the quantitation of microgram quantities of protein utilizing the principal protein-dye binding. Analyt Biochem 72:248-252

Dinu, D., Nechifor, M.T., Movileanu, L. 2005. Ethanol-induced alterations of the antioxidant defense system in rat kidney. J Biochem Mol Toxicology 19: 386-395.

Fridovich, I. 1986. Superoxide dismutase. Advance in Enzymology and Related Areas of Molecular Biology 58 :61-97

Gan, S. et al.1980. Farmakologi dan Terapi edisi ke-2. Jakarta: UI Press.

Gitawati, R. 1995. Radikal bebas: sifat dan peranan dalam menimbulkan kerusakan atau kematian sel. Cermin Dunia Kedokteran 102:33-36.

Gupta, A K., Chitme, H. Dass, S.K., Misra, N. 2006. Hepatoprotective activity of Rauwolfiaserpentina rhizome in paracetamol intoxicated rats. J. Pharmacol Toxixol. Methods 1: 82-88.

Hadi, S., Ediyanto, S.P., Djatmiko, W., dan Fuad, A. 1985. Pengaruh pemberian kurkuminoid (C. Domestica, Val) terhadap kadar kolesterol HDL serum tikus putih (Rattus norvegicus). Prosiding Simposium Nasional Temulawak. Universitas Padjajaran. Bandung. Hlm 170-177.

Halliwell, B., Gutteridge, J.M.C. 1989. Free Radical in Biology and Medicine $3^{\text {rd }}$ edition. New York: Oxford University Press.

Hasan, A.E.Z., Ambarsari, L., Artika, I.M., Julistiono H dan Tarunasari D. 2013. Induction resistance of Candida sp. Y 390 to ethanol stress by kopyor coconut 
and virgin coconut oil. Emir. J. Food Agric. 25 (10): 790-797.

Hidayatullah, S. 2006. Performa mencit (Mus musculus) jantan dan betina dengan suplementasi tepung temulawak (Curcuma xanthorrhiza Roxb.) dalam ransum [skripsi]. Bogor: Fakultas Peternakan, Institut Pertanian Bogor.

Kamath, P.S. 1996. Clinical approach to the patient with abnormal liver function test results. Mayo Clin Proc 71: 10841094.

Kartikawati, D. 1999. Studi efek protektif vitamin $\mathrm{C}$ terhadap respon imun dan enzim antioksidan pada mencit yang dipapar paraquat [tesis]. Bogor: Program Pascasarjana, Institut Pertanian Bogor.

Liang, O. B., Y. Apsarton, T. Widjaja dan S. Puspa. 1985. Beberapa aspek isolasi, identifikasi dan penggunaan komponenkomponen C. Xanthorriza, Roxb dan C. Domestica, Val. PT. Darya Varia Laboratoria. Prosiding Simposium Nasional Termulawak. Bandung. 101116.

Mates, J.M., Gomez, C.P, Castro. 1999. Antioxidant enzymes and human disease. Clin Biochem. 32 (8):595-603

Matjik, A.A., Sumertajaya. 2002. Rancangan Percobaan. Bogor: IPB Pr.

Nurwati, D. 2002. Profil imunohistokimia enzim antioksidan copper,zinc superoxide dismutase ( $\mathrm{Cu}, \mathrm{Zn}-\mathrm{SOD})$ pada ginjal tikus hiperkolesterolemia [skripsi]. Bogor: Fakultas Kedokteran Hewan, Institut Pertanian Bogor.

Ressang, A.A. 1984. Patologi Khusus Veteriner. Bali: Percetakan NV.

Santoso, et al. 1996. Nutrient composition of kopyor coconuts (Cocos nucifera L.). J Food Chem :57 no 2 : 299-304

Sulistyo, B.I. 2004. Radikal bebas, peroksidasi lipid, dan antioksidan. Cakrawala Pendidikan 1:55-61.
Tuminah, S. 2000. Radikal bebas dan antioksidan: kaitannya dengan nutrisi dan penyakit kronis. [terhubung berkala]

http://www.cerminduniakedokteran.co m. [18 Februari 2007].

West, C.W dan Prohaska, J.R. 2004. $\mathrm{Cu}, \mathrm{Zn}$-superoxide dismutase is lower and copper chaperone (CCS) is higher in erythrocytes of copper deficient rats and mice. Experimental Biol and Med 229:756-764

Winterbourn, C.C, Hawkins, M., Brian, C. 1975. The estimation of red cell superoxide dismutase activity. $J$ Lab Clin Med 85:337-342

Voet D dan Voet JG. 2004. Biochemistry, $3^{\text {rd }}$ edition. USA: John Wiley and Sons, Inc 